Jurnal Gizi dan Dietetik Indonesia (Indonesian Journal of Nutrition and Dietetics) Vol. 8, No. 1, 2020: 45-53

\section{Fruit and vegetable juice formulation for blood pressure control in hypertensive elderly}

\author{
Niken Widyastuti Hariati ${ }^{1}$, Rijanti Abdurrachim ${ }^{1}$ \\ 1 Nutrition Department, Ministry of Health Polytechnic of Banjarmasin, Jalan Haji \\ Mister Cokrokusumo No. 1A Banjar Baru, Kalimantan Selatan, Indonesia 70714 \\ *Corresponding author: niken.widyastuti.hariati@gmail.com
}

\begin{abstract}
ABSTRAK
Latar belakang: Lansia merupakan kelompok usia yang sangat rentan menderita hipertensi atau tekanan darah tinggi. Selain dengan obat, tekanan darah bisa dikontrol dengan pengelolaan pola makan. Beberapa buah dan sayuran yang dipercaya dapat membantu menurunkan tekanan darah seperti semangka, mentimun, tomat, sawi hijau, papaya dan pisang Ambon. Kandungan yang berperan antara lain kandungan air, serat, kalsium, kalium dan magnesium.

Tujuan: Penelitian ini bertujuan melihat efektifitas formulasi jus sayur dan buah terhadap pengendalian tekanan darah pada lansia hipertensi.

Metode: Metode penelitian secara Quasi Experiment dengan rancangan penelitian analisis varians satu arah berdasarkan Kruskal-Wallis dengan taraf signifikan 5\% $(\alpha=0.05)$ dan tingkat kepercayaan 95\%. Kelompok perlakuan diberikan intervensi berupa pemberian jus sayur dan buah dengan pengendalian standar makanan untuk menghasilkan standarisasi jus sayur dan buah yang efektif dalam pengendalian tekanan darah. Penelitian dilakukan di Panti Sosial Tresna Werdha Budi Sejahtera. Populasi penelitian adalah seluruh lansia hipertensi di Panti Tresna Werdha Budi Sejahtera sebanyak 108 orang dengan sampel penelitian menggunakan teknik purposive sampling sebanyak 81 orang dimana terdapat 27 kombinasi formula jus (9 kombinasi formula A, 9 kombinasi formula B, 9 kombinasi formula C). Pemberian tiap kombinasi diberi jeda satu hari dengan melihat perubahan tekanan darah 6 jam sebelum dan sesudah intervensi.

Hasil: Hasil penelitian didapatkan formula jus sayur dan buah yang paling efektif dalam pengendalian tekanan darah sistolik lansia yaitu kelompok formula B31 (tomat, sawi dan semangka) dan B32 (tomat, sawi dan pisang ambon) dengan $p=0.046$ atau tingkat kepercayaan $>95 \%$.

Kesimpulan: Perlu dilakukan uji lebih lanjut dengan jumlah sampel yang lebih besar terhadap kedua formula jus sayur dan buah ini untuk melihat seberapa jauh efektifitas penurunan tekanan darah yang dihasilkan. Hasil penelitian ini bisa menjadi bahan pertimbangan dalam pengaturan menu diet pada lansia dengan hipertensi.
\end{abstract}

KATA KUNCI: hipertensi; jus buah; lansia; sayuran

\begin{abstract}
Backgrounds: The elderly is an age group that is very vulnerable to suffer from hypertension. In addition to drugs, blood pressure can also be controlled by managing diet. Some fruits and vegetables that are believed to reduce blood pressure are watermelons, cucumbers, tomatoes, mustard greens, papaya and Ambonese bananas. Ingredients that play a role include mineral potassium, calcium and magnesium. Objectives: This study aims to look at the effectiveness of vegetable and fruit juice formulations on controlling blood pressure in elderly hypertension.

Methods: The research method is a Quasi Experiment with a one-way analysis of variance analysis design based on Kruskal-Wallis with a significance level of $5 \%(\alpha=0.05)$ and a confidence level of $95 \%$. The treatment group was given intervention in the form of giving vegetable and fruit juices by controlling food standards to produce an effective standardization of vegetable and fruit juices in controlling blood pressure. The study was conducted at Tresna Werdha Budi Sejahtera Social Home. The study population was all elderly hypertension at Tresna Werdha Budi Sejahtera Orphanage as many as 108 people with the study sample using purposive sampling techniques as many as 81 people where there were 27 juice
\end{abstract}


formula combinations (9 combinations of formula A, 9 combinations of formula $B, 9$ combinations of formula $C$ ). Giving each combination given a pause one day to see changes in blood pressure 6 hours before and after the intervention.

Results: The results showed that the most effective formulas of vegetable and fruit juices in controlling systolic blood pressure in the elderly were the formula group B31 (tomatoes, mustard greens and watermelons) and B32 (tomatoes, mustards and ambon bananas) with $p=0.046$ or a confidence level> $95 \%(\alpha=0,05)$.

Conclusion: Further tests need to be carried out with a larger number of samples of these two vegetable and fruit juice formulas to see how far the effectiveness of blood pressure reduction is produced and the results of this study can be taken into consideration in the regulation of diet menus in the elderly with hypertension.

KEYWORDS: elderly; fruit juices; hypertension; vegetable

\section{INTRODUCTION}

Hypertension is a cardiovascular disease that continues to increase every year and has a high prevalence. Epidemiologically, hypertension is estimated to be the cause of death around 7.1 million people in the world or about $13 \%$ of the total deaths.(1)

The results of the 2013 Basic Health Research showed that the prevalence of hypertension in Indonesia based on the measurement results at the age of $\geq 18$ years was $25.8 \%$, the highest in Bangka Belitung $(30.9 \%)$, followed by South Kalimantan (30.8\%), East Kalimantan ( 29.6\%) and West Java (29.4\%). (2)

Data from the South Kalimantan Provincial Health Office (2016) shows that as many as 51,022 people suffer from hypertension and in 2017 it increased to 154,343 people. This means that hypertension in South Kalimantan does need special attention. (3). Based on data taken from the Head of the Social Institution Tresna Werdha Budi Sejahtera as for the number of elderly people in the orphanage 178 people. From the data of health clinics in Panti, hypertension always occupies the top 3 most diseases every month in the range of 2016 to April 2018.

Control of blood pressure in patients with hypertension in addition to anti-hypertensive drugs and routinely controlling blood pressure, needs to be supported by proper dietary regulation. Eating regulation is important for people with hypertension by increasing sodium intake and consuming more food with a high content of potassium, calcium and magnesium, especially from vegetables and fruits. (4) Treatment of hypertension is also combined with various complex diuretic drugs such as hydrochlorothiazide and Lasix. These drugs are a class of drugs that greatly stimulate the release of body fluids through urine. (5)

Some types of fruits and vegetables are known to contain high potassium, calcium, and magnesium which are diuretic and play a role in maintaining acid-base balance, and help control heart muscle contraction and blood circulation (6), as well as being high in fiber and water content. So that it can naturally be used to help control blood pressure of hypertension sufferers. Several epidemiological studies show that diet has an important role in regulating blood pressure. One form of diet that is known to help control blood pressure is by reducing sodium intake, increasing potassium, calcium and potassium intake which is abundant in fruits and vegetables. (7-9) Research Appel LJ., et. al. (1997) also showed that with a diet rich in fruits and vegetables, or a "combination" diet rich in fruits, vegetables, and low-fat dairy products, both gave significant results for lowering blood pressure compared to the control group. Where the most reduction is on a combined diet of $5.5 \mathrm{mmHg}$ and a diet rich in fruits and vegetables $2.8 \mathrm{mmHg}$. (10)

Therefore, this research was conducted to see the effectiveness of giving various types of vegetable and fruit juice formulations on the control of hypertension in the elderly, carried out at Tresna Werdha Sejahtera Social Home, Banjarbaru City, South Kalimantan. 


\section{MATERIALS AND METHODS}

This research is a Quasi Experiment with a one-way analysis of variance analysis based on Kruskal-Wallis with a significance level of $5 \%$ $(\alpha=0.05)$ and a confidence level of $95 \%$. The independent variable in this study was the giving of vegetable and fruit juice formulations while the dependent variable was blood pressure control before and after the intervention.

The treatment group was given intervention in the form of giving vegetable and fruit juices with food standard control to produce an effective standardization of vegetable and fruit juices in controlling blood pressure. Vegetable and fruit juices in the form of a combination of cucumbers, tomatoes, mustard greens, watermelons, banana ambon, and papaya.

There are 27 combinations of vegetable and fruit juices. The combination of formula A: cucumber + watermelon (AA11), cucumber + banana ambon (AA12), cucumber + papaya (AA13), tomato + watermelon (AA21), tomato + ambon banana (AA22), tomato + papaya (AA23), mustard greens + watermelon (AA31), mustard greens + ambon banana (AA32), mustard greens + papaya (AA33),

The combination of formula $\mathrm{B}$ : cucumber + tomato + watermelon (BB11), cucumber + tomato + ambon banana (BB12), cucumber + tomato + papaya (BB13), cucumber + mustard greens + watermelon (BB21), cucumber + mustard greens + banana (BB22), cucumber + mustard greens + papaya (BB23), tomato + mustard greens + watermelon (BB31), tomato + mustard greens + ambon banana (BB32), tomato + mustard greens + papaya (BB33) .

The combination of formula C: cucumber + watermelon + ambon banana (CC11), tomato + watermelon + ambon banana (CC112), mustard greens + watermelon + ambon banana (CC13); cucumber + watermelon + papaya (CC21), tomato + watermelon + papaya (CC22), mustard greens + watermelon + papaya (CC23), cucumber + banana ambon + papaya (CC31), tomato + ambon banana + papaya (CC32), mustard greens + banana ambon + papaya (CC33).

Per cup as much as $200 \mathrm{ml}$ with a composition consisting of $140 \mathrm{ml}$ of vegetables \& fruit, $50 \mathrm{ml}$ of water, $5 \mathrm{ml}$ of honey and $5 \mathrm{ml}$ of lime water as a flavor and aroma enhancer. Food standardization for hypertensive elderly in accordance with the 2013 AKG for the elderly and anti-hypertensive drugs is still given to all hypertensive elderly people. This arrangement is carried out by coordinating with nutritionists, doctors and nurses at the Social Home.

This research was conducted at the Tresna Werdha Sejahtera Social Home, Banjarbaru, South Kalimantan from April until August 2019. The study population was all elderly hypertension at Tresna Werdha Budi Sejahtera Orphanage as many as 108 people with the study sample using purposive sampling techniques as many as 81 . .

Primary data consists of elderly food standard data by assessing food composition from the morning, afternoon and evening menus, calculating the sodium ( $\mathrm{Na}$ ) and potassium (K) content in elderly food standards according to the AKG 2013, the characteristics of research subjects obtained using a structured questionnaire. Systolic blood pressure control data before and after the intervention using Omron digital blood pressure monitor. Blood pressure measurement is carried out for 3 days with an interval of 1 day after the intervention. In each time blood pressure measurement, each respondent is measured a minimum of 2 times then averaged. Blood pressure measurements are carried out before and after the intervension, by looking at changes in blood pressure less then 6 hours after the intervension. Secondary data consists of agency profile data and data on the number of all elderly obtained by looking at records or records from the institution and data on the number of elderly people suffering from hypertension obtained by looking at records or records from health clinics at Tresna Werdha Budi Sejahtera Social Home.

After all, data were collected, the data were analyzed bivariate with the Kruskal-Wallis test in each treatment group. The group with a value of $\rho$ less than $\alpha(\alpha=0.05)$ was continued with the Mann-Whitney post hoc test until the most significant formulation of vegetable and fruit juice was found in controlling blood pressure. This data analysis was performed using SPSS statistical software. 


\section{RESULTS}

\section{Classification of Hypertension}

The distribution of respondents' systolic blood pressure categories before and after the intervention can be seen in Table 1.

Table 1 shows that prior to the intervention most respondents were categorized as 2 nddegree hypertension $(\geq 140 \mathrm{mmHg}$ ) of $64.2 \%$, firstdegree hypertension (130-139 $\mathrm{mmHg}$ ) of $28.4 \%$. After the intervention was given, hypertension of degrees 2 and 1 decreased to $53.1 \%$ and $19.75 \%$ shifted down to the category of increase / high
$(120-129 \mathrm{mmHg})$ by $19.75 \%$ and normal $(<120$ $\mathrm{mmHg}$ ) by $2.5 \%$.

Table 2 shows that after intervention as many as $63 \%$ of hypertensive elderly people experienced a decrease in systolic blood pressure, but there were also $37 \%$ who actually experienced an increase.

The bivariate test was then performed, which can be seen in Table 3 with the KruskalWallis test in the group of vegetable and fruit juice formulations which significantly decreased systolic blood pressure was in the formula B group with a value of $\rho 0.026$. So the differentiation test is then

Table 1. Distribution of systolic blood pressure categories of respondents before and after intervention

\begin{tabular}{lcccc}
\hline \multicolumn{1}{c}{$\begin{array}{c}\text { Category } \\
\text { Systolic Blood Pressure }\end{array}$} & \multicolumn{2}{c}{ Before Intervention } & \multicolumn{2}{c}{$\begin{array}{c}\text { After } \\
\text { Intervention }\end{array}$} \\
\cline { 2 - 5 } & $\mathbf{n}$ & $\%$ & $\mathbf{n}$ & $\%$ \\
\hline Normal $(<120 \mathrm{mmHg})$ & - & - & 2 & 2.5 \\
Increase / high $(120-129 \mathrm{mmHg})$ & 4 & 5 & 16 & 19.75 \\
1st degree hypertension $(130-139 \mathrm{mmHg})$ & 23 & 28.4 & 16 & 19.75 \\
2nd degree hypertension $(\geq 140 \mathrm{mmHg})$ & 52 & 64.2 & 43 & 53.1 \\
Critical hypertension $(>180 \mathrm{mmHg})$ & 2 & 2.5 & 6 & 7.4 \\
\hline Total & 81 & 100.0 & 81 & 100.0 \\
\hline
\end{tabular}

Table 2. Distribution of systolic blood pressure changes of respondents after intervention

\begin{tabular}{lcc}
\hline \multirow{2}{*}{ Systolic Blood Pressure } & \multicolumn{3}{c}{ Treatment group } \\
\cline { 2 - 3 } & $\mathbf{n}$ & $\%$ \\
\hline Decrease & 51 & 63.0 \\
Constantly & 0 & 0.0 \\
Increase & 30 & 37.0 \\
\hline Total & 81 & 100.0 \\
\hline
\end{tabular}

Table 3. Distribution of systolic blood pressure in the treatment group with the Kruskal Wallis test

\begin{tabular}{cccccc}
\hline $\begin{array}{c}\text { Systolic Blood } \\
\text { Pressure Control }\end{array}$ & $\begin{array}{c}\text { Mean Rank } \\
(\mathbf{m m H g})\end{array}$ & $\begin{array}{c}\text { Free Degrees } \\
(\mathbf{k}-\mathbf{1})\end{array}$ & H & P \\
\hline \multirow{2}{*}{ A } & A1 & 14.8 & & & \\
& A2 & 14.4 & 2 & 0.3 & 0.85 \\
& A3 & 12.8 & & & \\
B & B1 & 19.3 & & 7.3 & 0.026 \\
& B2 & 19.3 & 2 & & \\
& B3 & 9.3 & & & 0.32 \\
C & C1 & 13.6 & & & \\
& C2 & 17.0 & 2 & & \\
\hline
\end{tabular}


Table 4. Systolic blood pressure distribution in treatment B group with Mann Whitney U test

\begin{tabular}{lccc}
\hline $\begin{array}{c}\text { Systolic Blood Pressure } \\
\text { Control }\end{array}$ & B1 and B2 & Breatment group \\
\cline { 2 - 4 } & 20.0 & 13.0 & B2 and B3 \\
\hline Mann-Whitney U & -1.8 & -2.4 & 26.0 \\
Z & 0.1 & 0.015 & -1.3 \\
$\mathrm{P}$ & & & 0.2 \\
\hline
\end{tabular}

Table 5. Distribution of systolic blood pressure in the B1 treatment group with the Mann Whitney U test

\begin{tabular}{cccc}
\hline \multirow{2}{*}{ Systolic Blood Pressure Control } & \multicolumn{3}{c}{ Treatment group } \\
\cline { 2 - 4 } & B11 and B12 & B11 and B13 & B12 and B13 \\
\hline Mann-Whitney U & 3.0 & 3.0 & 4.0 \\
Z & -0.65 & -0.65 & -0.2 \\
P & 0.25 & 0.5 & 0.83 \\
\hline
\end{tabular}

Table 6. Systolic blood pressure distribution in the B3 treatment group using the Mann Whitney U test

\begin{tabular}{lccc}
\hline \multirow{2}{*}{ Systolic Blood Pressure Control } & \multicolumn{3}{c}{ Treatment group } \\
\cline { 2 - 4 } & B31 and B32 & B31 and B33 & B32 and B33 \\
\hline Mann-Whitney U & 0.0 & 3.0 & 1.0 \\
Z & -1.99 & -0.7 & -1.53 \\
$\mathrm{P}$ & 0.046 & 0.51 & 0.13 \\
\hline
\end{tabular}

performed on the formula group as shown in Table 4 with the Mann-Whitney $U$ test.

The Mann-Whitney $U$ test results in Table 4 where the treatment group with formulas B1 and B3 which significantly means there are differences in control of systolic blood pressure with a value of p 0.015 .

In the treatment sub-group with formulas B1 and B3, further tests were performed to see which combination was the most significant. Where is seen in Table $\mathbf{5}$ there is no significant difference in blood pressure control in the subformula B1 (B11 and B12; B11 and B13; B12 and B13).

While in Table 6 seen in the sub-group formula B3 (B31 and B32) it is said that there is a significant control of systolic blood pressure before and after the intervention is given, where the value of $\rho 0.046$ is smaller than $\alpha=0.05$. so it is said that there are differences in control of systolic blood pressure in formulas B31 and B32. B31 is a vegetable and fruit juice formula combination of tomatoes, mustard greens, and watermelons. B32 is a vegetable and fruit juice formula combination of tomatoes, mustard greens and ambon bananas.

\section{DISCUSSIONS}

\section{Overview of Systolic Blood Pressure}

Hypertension or high blood pressure is a condition where a person experiences an increase in blood pressure above normal which is indicated by systolic and diastolic numbers on blood pressure checks using a blood pressure gauge either manually (sphygmomanometer) or digital and has been diagnosed by health personnel. Classification of blood pressure in adults based on the AHA Guideline (2017) classifies hypertension from the category; Increased / high (systolic 120-129 mmHg), first-degree hypertension (systolic 130-139 mm Hg), second-degree hypertension (systolic $\geq 140 \mathrm{mmHg}$ ) and critical hypertension (systolic> $180 \mathrm{mmHg}$ ). (11)

Before the intervention, all elderly respondents had hypertension and had increased blood pressure. From the results of the study note that prior to the intervention of giving formula of vegetable and fruit 
juices, most respondents (64.2\%) had a pressure of $\geq 140 \mathrm{mmHg}$ or second-degree hypertension (Table 1.). Blood pressure monitoring is carried out the morning before and the evening after the intervention with a vulnerable measurement time of less than 6 hours. Blood pressure measurement is carried out for 3 days with an interval of 1 day after the intervention. In each time blood pressure measurement, each respondent is measured a minimum of 2 times then averaged. Changes in systolic blood pressure after the intervention as much as $63 \%$ of respondents experienced a decrease in blood pressure, but there were $37 \%$ who actually experienced an increase (Table 2).

High blood pressure or hypertension is influenced by various factors. After dietary factors, activity patterns and the use of blood pressurelowering drugs are controlled, one factor that is difficult to control is the stress factor. In the results of Seke's research (2016), there was a significant relationship between the incidence of stress and the level of hypertension. High blood pressure or hypertension can be caused by the stress suffered by an individual because the reaction that appears to stress impulses is an increase in blood pressure. In addition, most individuals who experience stress have difficulty falling asleep, so that it will have an impact on their blood pressure which tends to be high. (12)

The elderly who live in Tresna Werdha Budi Sejahtera Social Home have different backgrounds in life and reasons. In line with Indriana et. a.I (2010) that the background, reasons and current conditions in each institution contribute as a stressor or source of stress for the elderly at the Social Home. Of course, the contribution of stress from each of these stressors will differ depending on the individual factors as well. The size of the contribution of stress from stressors that surround the lives of elderly orphans will provide a variation on the level of stress experienced. (13)

Some respondents also admitted that it was difficult to sleep at night so that respondents get poor sleep quality. This is supported by Havisa (2014) which states that increasing age will cause changes in physiological function, especially a decrease in the amount of sleep time needed and sleep well. Poor sleep quality is also associated with an increase in blood pressure. Inadequate quality and quantity of sleep can damage memory and cognitive abilities. If this continues for years, it will have an impact on high blood pressure, heart attacks, strokes, and psychological problems such as depression and other mood disorders. (14)

\section{Systolic Blood Pressure Control}

Several studies have shown that there is an effect of giving several types of vegetable and fruit juices to control systolic blood pressure. This change in systolic blood pressure may be due to an increase in potassium, calcium and magnesium intake through the addition of consumption of vegetables and fruit into the elderly's daily menu.

The results of bivariate analysis with the Kruskal-Wallis test in the treatment group combination of formulas $\mathrm{A}, \mathrm{B}$ and $\mathrm{C}$ showed that in the treatment group combination of formula $B$ the value $\rho=0.026(\rho<\alpha=0.05)$ showed that there was control of systolic blood pressure in the combination of formula B (B1, B2, B3) (Table 3).

The analysis then continued with the post hoc test with the Mann-Whitney test, which is a comparison test by comparing blood pressure control in the groups' B1 and B2 ', B1 and B3' and 'B2 and B3'. The value of $\rho=0.015$ was significant ( $\rho$ $<\alpha=0.05$ ) only in the B1 and B3 groups '(Table 4).

From these results further tests were carried out to see blood pressure control in the B1 formula group consisting of 'B11 and B12', B11 and B13 'and' $B 12$ and $B 13$ '. And the $B 3$ formula group consists of 'B31 and B32', 'B31 and B33 and' B32 and B33 '. In the follow-up test results, the value of $\rho=0.046$ is significant in the formula 'B31 and B32' which shows that there is significant blood pressure control in the treatment group (Table 5).

Formula B31 is a combination of tomato, mustard and watermelon juice. Formula B32 is a combination of tomato juice, mustard greens and ambon bananas. Each with a composition of 200 $\mathrm{ml}$ in the form of a mixture of $140 \mathrm{ml}$ of vegetables and fruit, $50 \mathrm{ml}$ of water and $10 \mathrm{ml}$ of a mixture of honey and lime to add flavor and aroma. 
Vegetables and fruits are very rich in fiber, vitamins and minerals. Especially the minerals potassium, calcium and magnesium which are known to play a role in helping control high blood pressure. In 25 grams of tomatoes and 25 grams of mustard greens each contain $57 \mathrm{mg}$ and 89 $\mathrm{mg}$ of potassium. The highest potassium is found in mustard greens. In addition to the content of potassium in the formula of vegetable and fruit juices, it also contains other minerals that support blood pressure control, namely the content of calcium and magnesium.

The combination of cucumber and tomato has a high calcium and magnesium content. In 25 grams of cucumber ingredients containing $3.5 \mathrm{mg}$ of calcium and Magnesium $3 \mathrm{mg}$ and tomatoes containing $5.5 \mathrm{mg}$ of calcium. The combination of tomatoes and mustard greens contains calcium and magnesium too. The mustard greens contain the highest calcium and magnesium are $30 \mathrm{mg}$ and 19.7 $\mathrm{mg}$ and the highest potassium is $89.5 \mathrm{mg}$.

A combination of mustard tomatoes added with watermelon, banana, and papaya (25 grams each) which also contains calcium, magnesium and potassium. The addition of watermelons, bananas and papaya turned out to add high potassium levels, especially from ambon bananas.

Potassium, calcium, and magnesium of each of these minerals have a role in helping control blood pressure. Potassium helps control blood pressure by causing vasodilation effects, causing total peripheral retention. Potassium plays a role in maintaining fluid and electrolyte balance as well as acid and base balance. (6) Potassium also has a diuretic effect so that the secretion of liquid sodium increases and potassium is also useful to inhibit the Renin-Angiotensin System (RAS) so that a decrease in aldosterone secretion causes a decrease in reabsorbsi sodium and water directly on the kidneys.

This is in line with the results of Amran, Y. (2010) research that the additional intake of potassium derived from fruits in the diet has succeeded in reducing systolic blood pressure. (15)

Studies conducted on potassium content can reduce blood pressure, among others clinical research with the administration of potassium proves that potassium can reduce blood pressure greater in patients with hypertension by $4.4 \mathrm{mmHg}$ in systolic blood pressure and $2.5 \mathrm{mmHg}$ in diastolic blood pressure compared with the normotensive group of $1.8 \mathrm{mmHg}$ in systolic blood pressure and $1.0 \mathrm{mmHg}$ in diastolic blood pressure. (16)

Magnesium is one of the important minerals needed by the body and plays a role in biological processes, namely digestion, blood cell communication, muscle movements and the circulatory system. Magnesium helps maintain heart health by maintaining heart rhythm and controlling blood pressure to remain normal so that blood circulation remains smooth. Magnesium deficiency can affect blood pressure. While calcium plays an important role in the dilation and narrowing of blood vessels and helps regulate blood pressure. (6) A study was also carried out on pralanced women with insufficient levels of potassium having a risk of developing hypertension by 10.00 times compared with pralanced women with good levels of potassium. (17)

The results of Amran, Y. (2010) show the results that the additional intake of potassium derived from fruits in the diet has succeeded in reducing systolic blood pressure. In addition, additional fruits also increase calcium and magnesium intake. (15) Potassium is to encourage excessive sodium release thereby reducing preload (the initial burden of heart contraction) and lowering blood pressure, while magnesium reduces the strength of heart muscle contraction and skeletal muscle.

Calcium plays an important role in extracellular and intracellular fluids, which regulates cell functions, such as contraction of blood clots and maintain cell membrane permeability. (6) Calcium supplementation trials in pregnant women conducted to prevent hypertension indicate that pregnant women who receive calcium supplementation are at greater risk lower to hypertension $(R R=0.65$, $95 \% \mathrm{Cl}, 0.53-0.81)$ and pre-eclampsia $(R R=0.45$, $95 \% \mathrm{Cl}, 0.31-0.65)$ compared to those who only received placebo. (18) 


\section{CONCLUSION AND RECOMMENDATION}

Most of hypertension elderly who were research respondents at Tresna Werdha Budi Sejahtera Social Home are at the vulnerable age of 60-74 years, male sex and all have a family history of hypertension.

From 27 types of combinations of vegetable and fruit juice formulas given, there are 2 types of vegetable and fruit juice formulas that significantly influence the control of hypertension in the elderly, namely B31 (tomato, mustard green, and watermelon) formula and B32 (tomato, mustard green and ambon banana). Each combination of vegetable and fruit juices in formulas B31 and B32 contains high potassium, magnesium and calcium.

Further research needs to be done for both the combination of formula B31 (tomato, mustard green, and watermelon) and B32 (tomato, mustard green and ambon banana) with a larger number of respondents to see the significance level of blood pressure reduction per formula.

\section{REFERENCES}

1. Gu Q. Hypertension among adults in the United States: national health and nutrition examination survey, 2011-2012. 2013.

2. Indonesia KKR. Riset kesehatan dasar 2013. Jakarta: Kementerian Kesehatan Republik Indonesia. 2013;209.

3. Selatan DKPK. Penyakit Terbanyak Tahun 2016 dan 2017. Banjarmasin: Dinas Kesehatan Provinsi Kalimantan Selatan, 2018.

4. Kresnawan T. Asuhan Gizi Pada Hipertensi. Gizi Indonesia. 2011;34(2).

5. Fridalni N, Sapardi Sofiaa V. Pengaruh Pemberian Jus Semangka (Cilitrus Vulgaris Schrad) Terhadap Penurunan Tekanan Darah Lansia Dengan Riwayat Hipertensi Di Kota Padang. Naskah Publikasi Stikes Bercu Bakti Jaya Padang. 2013.

6. Almatsier S. Prinsip dasar ilmu gizi, PT. Gramedia Pustaka Utama, Jakarta. 2010.

7. Elford J, Phillips A, Thomson A, Shaper A. Migration and geographic variations in blood pressure in Britain. BMJ. 1990;300(6720):291-5.
8. Group ICR. Intersalt: an international study of electrolyte excretion and blood pressure. Results for 24 hour urinary sodium and potassium excretion. BMJ: British Medical Journal. 1988:319-28.

9. Young DB, Lin H, McCabe RD. Potassium's cardiovascular protective mechanisms. American Journal of Physiology-Regulatory, Integrative and Comparative Physiology. 1995;268(4):R825-R37.

10. Appel LJ, Moore TJ, Obarzanek E, Vollmer WM, Svetkey LP, Sacks FM, et al. A Clinical Trial of the Effects of Dietary Patterns on Blood Pressure. New England Journal of Medicine. 1997;336(16):1117-24.

11. Whelton PK, Carey RM, Aronow WS, Casey DE, Collins KJ, Dennison Himmelfarb C, et al. 2017 ACC/AHA/AAPA/ABC/ACPM/AGS/ APhA/ASH/ASPC/NMA/PCNA Guideline for the Prevention, Detection, Evaluation, and Management of High Blood Pressure in Adults. A Report of the American College of Cardiology/American Heart Association Task Force on Clinical Practice Guidelines. 2018;71(19):e127-e248.

12. Sukadiyanto $S$. Stress dan Cara Menguranginya. Cakrawala Pendidikan. 2010(1).

13. Indriana $Y$, Kristiana I, Sonda A, Intanirian A. Tingkat stres lansia di panti wredha "pucang gading" semarang. Jurnal Psikologi Undip. 2010;8(2).

14. Havisa R, Sugiyanto S. Hubungan Kualitas Tidur Dengan Tekanan Darah Pada Usia Lanjut di Posyandu Lansia Dusun Jelapan Sindumartani Ngemplak Sleman Yogyakarta: STIKES Aisyiyah Yogyakarta; 2014.

15. Amran Y, Febrianti F, Irawanti L. Pengaruh tambahan asupan kalium dari diet terhadap penurunan hipertensi sistolik tingkat sedang pada lanjut usia. Kesmas: National Public Health Journal. 2010;5(3):125-30.

16. Batin WOS, Saptaputra S. Pengaruh Pemberian Jus Mentimun + Pepaya + Semangka Terhadap Penurunan Tekanan Darah Sistolik Dan Diastolik Penderita Hipertensi Di Wilayah Kerja Puskesmas Liya Kabupaten Wakatobi Tahun 
2017. Jurnal IImiah Mahasiswa Kesehatan Masyarakat Unsyiah. 2007;2(6).

17. Wahyuni T, Widajanti L, Pradigdo SF. Perbedaan Tingkat Kecukupan Natrium, Kalium, Magnesium dan Kebiasaan Minum Kopi pada Pralansia Wanita Hipertensi dan Normotensi (Studi di Wilayah Kerja Puskesmas Kedungmundu Kota
Semarang Tahun 2016). Jurnal Kesehatan Masyarakat (e-Journal). 2016;4(2):68-75.

18. Hofmeyr GJ, Lawrie TA, Atallah ÁN, Duley L, Torloni MR. Calcium supplementation during pregnancy for preventing hypertensive disorders and related problems. Cochrane database of systematic reviews. 2014(6). 